\title{
MILITARY AND DEMOGRAPHIC INTER-LINKAGES IN THE CONTEXT OF THE LITHUANIAN SUSTAINABILITY
}

\author{
Ieva MEIDUTÉ-KAVALIAUSKIENE் (D) ${ }^{*}$, Gitana DUDZEVIČIŪTE் (D)2, \\ Nijolè MAKNICKIENE் (D) 3 \\ ${ }^{1,2}$ General Jonas Žemaitis Military Academy of Lithuania, \\ Šlo g. 5A, LT-10322 Vilnius, Lithuania \\ ${ }^{3}$ Vilnius Gediminas Technical University, Sauletekio al. 11, LT-10223 Vilnius, Lithuania
}

Received 11 April 2020; accepted 18 August 2020

\begin{abstract}
This paper aims at investigating military and demographic inter-linkages in the context of the Lithuanian sustainability. The investigation combines three important economic aspects such as demographic, military and sustainable development. The authors have revealed that demographic trends should be seen as a necessary conditions for ensuring the functioning of the military sector contributes to public security and sustainable development in general. Correlation and stepwise regression analysis, also Monte Carlo forecasting method have been applied for this purpose. Research results have revealed statistically significant interrelationship between military personnel as a share of total labour force and population growth rate, population median age, total fertility rate as well as birth rate. Moreover, Monte Carlo forecasting method allowed revealing for the next 10 years a steady slight increase in armed forces personnel, stable population growth rates, a rapid aging process and a slight decline of total fertility rate. Military and demographic estimations and future projections allow government to incorporate information into planning and sustainable development policy. The insights from this research may contribute to implementing the goals of sustainable development related to eradication of poverty, inequality, social exclusion, improvement in education, well-being and employment and tackling climate change.
\end{abstract}

Keywords: military, demographic, sustainable development, Lithuania, trends.

JEL Classification: J00, J11, J13, J19.

\section{Introduction}

Demographic trends, including population ageing, population growth, migration and urbanization have important implications for military service and sustainable development. Population estimates and future projections allow governments to predict demographic trends and incorporate information received into planning and development policy (United Nations, 2019). Moreover, demographic trends show impact on military service and security (Libicki

*Corresponding author. E-mail: ieva.meidute@lka.lt

Copyright (c) 2020 The Author(s). Published by Vilnius Tech Press

This is an Open Access article distributed under the terms of the Creative Commons Attribution License (http://creativecommons. org/licenses/by/4.0/), which permits unrestricted use, distribution, and reproduction in any medium, provided the original author and source are credited. 
et al., 2011). Over the period 2013-2019, the number of total military personnel in Lithuania increased by almost 87 per cent, military expenditure tripled and military expenditure as a share of real GDP grew up from 0.76 to 2.03 per cent (NATO, 2019). These military trends have been caused by growing insecurity and conflicts in the world. The study of the United Nations (2019) revealed the following demographic trends: 1) the global population is still growing, but some countries are experiencing a decline in their total population; 2) all countries are experiencing population ageing; 3) the levels of population fertility and mortality have declined around the globe; 4) international migration has become an important determinant of population change. Over 2019-2050, the population in 55 countries are projected to decrease due to low levels of fertility or high rates of emigration. The largest relative reduction in population size is expected in Lithuania, Latvia, Bulgaria and Ukraine. In these countries, over the period in question the losses will make around 20 per cent (United Nations, 2019). The change in population presents challenges for sustainable development related to poverty, inequality, well-being, promoting productive employment and making human settlements safe and sustainable (United Nations, 2017). Population ageing shows a strong impact on military service and sustainable development. As people get older, their needs, health and what they value can change.

Statement of the problem: it should be noted, that in the context of military and demographic relationship, there is a lack of studies involving the case of Lithuania. Moreover, the originality of the study lies in the lack of research that combines three important economic aspects such as demographic, military and sustainable development. Also, this research expands the range of scientific studies and may be an incentive for other researchers to conduct similar investigations in their own countries and to compare the obtained results with Lithuania. Therefore, the current paper extends the relevant analysis and provides some insights for the policy of sustainable development in Lithuania. The research addresses the problem of whether demographic trends have any impact on military trends in the context of implementing the sustainable development goals in Lithuania.

Object of the research: military and demographic interrelations in the context of sustainability.

Aim of the research: this research aims at providing more reliable estimates of the military and demographic relationship in the context of the sustainable development in Lithuania.

The remainder of this paper is organized as follows. The next section presents a literature review that provides the brief introduction to the research area. Section 2 introduces the methodology that was used for processing of this article. In this part we briefly described the problem statement, we derived article objectives and we provided the research procedure. Section 3 provides main results of this research. Finally, the article is finished by conclusions.

\section{Literature review}

Understanding global population trends and predicting demographic changes have become the key factors to the achievement of the goals of 2030 Agenda for Sustainable Development. The tendencies of population growth and ageing as well as fertility, mortality and interna- 
tional migration are the integral to sustainable development (United Nations, 2019). The European Union countries face a rapid decline in their population fertility. Also, population ageing is not only a demographic problem, as it impacts on the entire economy, especially in the area of expected decline in number of people of productive age and healthcare (Arltová et al., 2016). Taking into consideration these factors, there is a need to estimate the demographic trends as well as find answers to the key questions regarding the military sector and security of the country. Thompson (1929) developed a demographic transition model, which shows the population dynamics that countries may expect as they develop, the impact of development on fertility and demonstrates that demography is a long-term discipline (Prokurat \& Fabisiak, 2018). Malthus (1978) first put forward the concept of demographics as a variable in economic studies. Economic growth, peace and justice are at the centre of sustainable development. Sustainability aims towards both justice and efficiency with respect to human-nature relationship over the long-term (Baumgärtner \& Quaas, 2010). Sustainable development can be achieved with an optimal balance of demographic, economic and environmental development. Demographic sustainability should be seen as a necessary condition for sustainable development in general (Vasyltsiv \& Tesliuk, 2020).

It is notable, that demographic tendencies in different ways affect the military sector, because it is sensitive to population age, health, migration, and well-being. According to Hartley (2011), military requires labour as an input into the military production function. Military labour markets have some distinctive characteristics, such as (Hartley, 2011): 1) military demand involves search and recruitment, factor substitution, motivation and retention; 2) military supply embraces demography, human capital issues regarding training, skill acquisition and transferability; 3) military personnel are subject to discipline, which requires operating in hazardous conditions, working long hours with the probability of injury and death, liability to deployment to any place of the world; 4) military personnel and equipment embrace the life-cycle. The period of 40 years involves the processes of personnel recruitment, training, retention and retirement. Equipment life-cycle might be 50 years and embraces development, production, operation, maintenance and disposal. Many studies have been conducted regarding issues of military, revealing the most relevant aspects such as military health and military contribution to economic growth.

The research of Guo et al. (2019) reported the health effects of mindfulness-based stress reduction among 49 Chinese military recruits. Participants were randomized into a mindfulness-based stress reduction and a waitlist group. The findings revealed, that mindfulnessbased stress reduction group showed bigger improvement in mindfulness and general health, as well as bigger stress reduction compared to the waitlist group. The investigation suggested that mindfulness-based stress reduction could be a promising health intervention for improving health and reducing stress in military recruits of China. The purpose of Foster et al. (2017) study was to compare sleep disorders between male and female in the US military sector. The investigation focused also on comorbid behavioural health disorders and chronic pain in relation to sleep disorders. The study involved 209 military personnel with 52\% men with a mean age of 34 years. The research has concluded that gender-related differences in sleep disorders are present in active-duty personnel. Behavioural health disorders were frequent comorbid disorders, and women diagnosed greater psychiatric comorbidity 
than men (Foster et al., 2017). Moreover, Vest et al. (2018) explored differences in alcohol problems as a function of military status among US Army Reserve and National Guard soldiers and their partners. The research sample included 772 male and female participants who completed both the baseline and first follow-up assessments. The results have indicated that former male soldiers are at greater risk of alcohol problems than current soldiers and civilian spouses. Taking into consideration, that alcohol use may increase, the authors recommend that health care and service providers should consider screening and monitoring soldiers who separate from the military. Chou et al. (2016) investigated the relationship between sleep problems, depression level and coping strategies among military personnel. The results of the research have indicated that sleep quality, physical illness and alcohol consumption are associated with the mental health of military personnel. The authors agree, that focus on treating these factors may improve the mental health of military personnel and enhance effective coping strategies. In addition, Breland et al. (2017) investigated how military experience could influence women's eating habits. The findings described the ways military environment affected eating habits such as by promoting fast, irregular and disrupting the reward value of food. Participants believed that poor eating habits continued after military service. Also, participants reported military-related stressors including military sexual trauma and the need to meet military weight requirements in general and after giving birth. Moreover, military service can result in poor socialization and poor eating habits.

The second most popular topic in the recent studies is related to military expenditure and economic growth. Scientific studies (Yildirim \& Sezgin, 2003; Kalyoncu \& Yucel, 2006; Alptekin \& Levine, 2012; Anwar et al., 2012; Danek, 2013; Dunne \& Tian, 2015; Karadam et al., 2017; Markowski et al., 2017; Phiri, 2017; Zhang et al., 2017; d'Agostino et al., 2018; Utrero-Gonzalez et al., 2019; Saba \& Ngepah, 2019; Lin \& Wang, 2019; Meiduté-Kavaliauskienè et al., 2020; Dimitraki \& Win, 2020) have revealed positive as well as negative, also neutral effects of military on economic growth. However, the researchers agree that increased security and stability reinforces the positive link with economic growth (Utrero-Gonzalez et al., 2019). Shahbaz et al. (2013) presented two pathways through which military expenditure may have a positive impact on economic development. Through the first channel rising in military spending may increase aggregate demand by stimulating output, making attractive conditions for investments and ultimately promoting economic growth. Through the second channel increase in military expenditure may also lead to infrastructure improvements, technological advances. In addition, Dunne et al. (2005) focused on security effects of military spending, because a stable security situation is essential in respect of market efficiency. Utrero-Gonzalez et al. (2019) studied the impact of participating in a military alliance on the nexus between defence spending and economic growth. The findings have shown that the prospect of intensified military alliance partnership has a positive effect on economic growth. Moreover, increased security and stability due to closer military cooperation reinforces the positive relation with economic development. Also, the studies very often reveal negative effect of military expenditure on economic growth, which has been explained by the fact that diverting large resources towards military would leave other economic areas with less financing. The study of Yang 
et al. (2011) reported that military spending had a significantly negative relationship with economic growth in 23 less wealthy countries. The authors did not find any significant relationship in other 69 more wealthy countries. Moreover, Shahbaz et al. (2013) concluded that in the case of Pakistan an increase in military spending reduced the pace of economic growth. The investigation of Dunne and Tian (2015) showed the effect of military spending on economic growth in 106 countries in 1988-2010. The researchers found negative and significant effect in a short-run for all observed groups of countries and negative and significant impact in a long-run for the high-income and low-income groups of countries. The findings of Dimitraki and Win (2020) reveal positive short - and long-run relationships between military expenditure and economic growth in Jordan. This insight has important policy implications for Jordan, as it justifies the transfer of resources to the military. The Figure 1 below displays the inter-linkages of demographic trends, military sector and Sustainable development. Demographic information is essential for military sector as well as for assessing progress towards the achievement of the Sustainable development goals. Countries can adapt to demographic situation by predicting the trends and incorporating respective information into policies (United Nations, 2019). Moreover, it has been reported that the armed forces of the US are going green. The Department of Defence has decided to obtain a quarter of its energy from renewable resources, to cut energy intensity and petroleum use, obtain a quarter of its energy from renewable resources and significantly reduce its greenhouse gas emissions (Becker, 2011). According to Becker (2011), if defence sector achieves its energy efficiency and renewable energy goals, it will give significant environmental benefits.

The impact of demographic trends on military services and sustainable development goals can be both direct and indirect. The direct effect is that larger countries can raise proportionally more fighters. The indirect impact is that demographic factors affect economic growth and thus defence expenditure (Libicki et al., 2011).

To conclude, demographic trends, including population ageing, population fertility, mortality and international migration have important implications for military service and sustainable development. Military sector is sensitive to population age, health, migration, and well-being. In many cases the interrelationship between military spending and economic growth has been detected, yet reports display different results. However, a stable security situation is vital in respect of market efficiency and economic growth, leading towards sustainability.

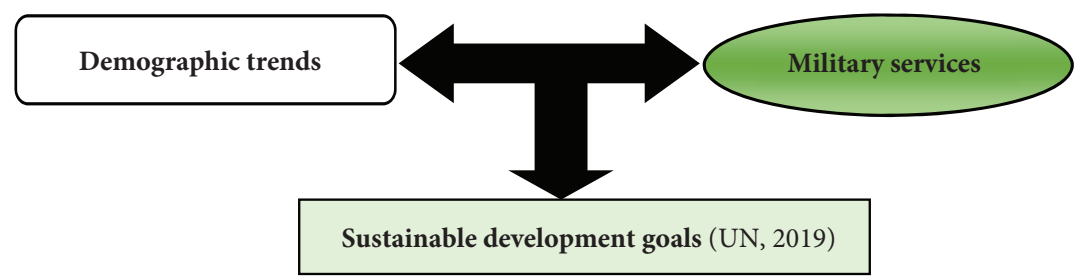

Figure 1. Inter-linkages of demographic trends, military sector and sustainable development (source: made by authors) 


\section{Methodological approach}

Indicators that reflect militaristic and demographic changes per year have been selected for research, and their interconnectedness may reveal the components of sustainable development.

Armed forces personnel (\% of total labour force). Armed forces personnel are active duty military personnel, including paramilitary forces if the organization, training, equipment, and control suggest they may be used to support or replace regular military forces (World Bank, 2019). This indicator reflects the changes in the employment of military people in the sector with valuation changes in labour market of Lithuania.

Demographic factors reflecting changes in the country have been chosen referring to the studies of international organizations, such as United Nations $(2017,2019)$ and World Bank (2016), also the scientific research of Lutz et al. (2006), Arltová et al. (2016), Prokurat and Fabisiak (2019) and Vasyltsiv and Tesliuk (2020). Taking into consideration that the military sector demands young people and they make up the majority of emigrants, we have additionally included the growth rate of emigration in the study and identified the impact of its dynamics on military personnel. Moreover, by linking sustainable development with the country's demographic indicators, the authors emphasize the stability of the population structure (Knell, 2005). There must be enough young people in the country, a similar number of people have to enter the labor market as they have to leave the labor market because of old age. López Subires et al. (2019) draw attention to the constant changes in all countries: a decrease in fertility and fertility, an increase in active life expectancy. Salvati et al. (2019) include the migration balance, the mortality rate and the urbanization rate in the study of sustainable development. Based on previous studies, the following demographic indicators have been identified and used in this research:

- population growth rate shows how fast growth or shrinking of the community in a country is (Eurostat, 2019);

- population median age reflects the ageing of population and is calculated like the age that divides a population into two numerically equal groups, meaning half the people are younger than median age and half are older (Eurostat, 2019);

- total fertility rate can be interpreted as the mean number of children that would be born alive to a woman during her lifetime if she were to pass through her childbearing years conforming to the fertility rates by age of a given year, and surviving (Eurostat, 2019);

- birth rate reflects natural growth (Eurostat, 2019);

- mortality rate or death rate, reflects the natural decline of the population (Eurostat, 2019);

- the growth rate of emigration. It is an important indicator reflecting the change in the country's population. Emigration in Lithuania is significantly higher than immigration.

The changes in demographic indicators present challenges for sustainable development goals related to well-being, poverty, inequality, social exclusion and promoting productive employment in military sector.

Correlation analysis, stepwise regression analysis and Monte Carlo forecasting method were used to study the impact of demographic trends on military and sustainable development. 
Correlation analysis was performed using Pearson coefficient, which is significant when greater than 0.6 or less than -0.6 .

Stepwise regression analysis is a set of rules designed to obtain a multiple regression equation with a good reliability index between a dependent variable and several independent variables. Direct stepwise regression analysis consists of the following steps:

1. Performing a regression analysis between the dependent variable $y$ and each independent variable separately. The factor $\mathrm{k}$ with the smallest $\mathrm{p}$-value is selected.

2. Performing a regression analysis between the dependent variable $y$ on factor $\mathrm{k}$ and each of the other independent variables. Again, the factor with the lowest $\mathrm{p}$ is found.

The operation is repeated to the point, where $\mathrm{p}<0.05$ and a sufficiently reliable equation is obtained. Our investigation used Matlab stepwise algorithm.

The Monte Carlo-based method is a numerical algorithm based on statistical simulation and statistical processing of the results obtained, and is often referred to as "statistical modeling". Monte Carlo methods are commonly used when it is not possible to obtain accurate results using a deterministic algorithm. The essence of this method is the modeling of random situations with the help of a certain procedure, resulting in a random result. The results obtained are processed using mathematical statistical methods, the types and parameters of the random variables distribution (e.g. mean, variance, mean square deviation and other numerical characteristics) are determined. Many algorithms are developed and included in the software package that use the Monte Carlo-based method. Our selected algorithm is VEC Model Monte Carlo Forecasts from Matlab (MatLab, 2019). It shows how to generate Monte Carlo forecasts from a VEC (q) model. The example compares the generated forecast to the minimum mean squared error (MMSE) forecast and prediction from the VAR ( $q+$ 1) model of the VEC (q) model. Forecasting using the Monte Carlo method includes the following steps:

- Collection and preparation of data.

- Evaluation of the VEC model using observation data.

- Predictions are created from the calculated model.

- Plot historical observations, mean forecasts, and 95\% percentile confidence intervals.

The graphically presented forecast illustrates the dynamics of the projected indicator for 10 years into the future and possible marginal scenarios.

\section{The investigation of the relationships between the variables and forecasting}

\subsection{Correlation and regression analysis}

Correlation analysis was performed to determine the relationship between military indicators and demography indicators. Correlation coefficients are shown in Table 1. Armed Forces Personnel (\% of total labour force) shows a positive correlation with population Median age (0.89). Other coefficients show no significant correlation.

The relationship between Armed Forces Personnel and ageing can be explained by the fact that both rates increased between 1992 and 2019, Armed Forces Personnel used to change at first faster and then slightly slower, and the ageing rate changed consistently. 
Table 1. Correlation coefficients between military and demography indicators (source: World Bank, 2019; Eurostat, 2019)

\begin{tabular}{|c|c|c|c|c|c|c|}
\hline $\begin{array}{c}\text { Armed forces } \\
\text { personnel }^{*}\end{array}$ & $\begin{array}{c}\text { Population } \\
\text { growth rate }\end{array}$ & $\begin{array}{c}\text { Population } \\
\text { median age }\end{array}$ & $\begin{array}{c}\text { Total fertility } \\
\text { rate }\end{array}$ & Birth rate & $\begin{array}{c}\text { Mortality } \\
\text { rate }\end{array}$ & $\begin{array}{c}\text { Emigration } \\
\text { growth rate }\end{array}$ \\
\hline 1 & -0.50248 & 0.89045 & -0.19185 & 0.330492 & 0.361009 & 0.168339 \\
\hline
\end{tabular}

${ }^{*}$ Armed forces personnel (\% of total labour force).

Belsley collinearity diagnostics assess the strength and sources of collinearity among variables in a multiple linear regression model. Belsley's simulation experiments suggest that condition indices in the range of 5 to 10 reflect weak dependencies, and those in the range 30 to 100 reflect moderate to high dependencies (Table 2).

Table 2. Belsley collinearity diagnostics

\begin{tabular}{|c|c|c|c|c|c|c|}
\hline sValue & $\begin{array}{c}\text { Condition } \\
\text { indices }\end{array}$ & $\begin{array}{c}\text { Armed forces } \\
\text { personel }\end{array}$ & $\begin{array}{c}\text { Population } \\
\text { growth rate }\end{array}$ & $\begin{array}{c}\text { Population } \\
\text { median age }\end{array}$ & $\begin{array}{c}\text { Total } \\
\text { fertility }\end{array}$ & Birth rate \\
\hline 1.9833 & 1 & 0.0011 & 0.0072 & 0.0001 & 0.0002 & 0.0046 \\
\hline 0.9546 & 2.0776 & 0.0005 & 0.0060 & 0.0000 & 0.0000 & 0.4907 \\
\hline 0.3366 & 5.8913 & 0.0318 & 0.7954 & 0.0005 & 0.0008 & 0.0451 \\
\hline 0.2033 & 9.7532 & 0.2194 & 0.0717 & 0.0024 & 0.0224 & 0.2237 \\
\hline 0.0290 & 68.3981 & 0.7472 & 0.1197 & 0.9970 & 0.9767 & 0.2358 \\
\hline
\end{tabular}

Further, performing stepwise regression analysis, six demographic indicators were included in the search for the linear regression equation. Stepwise regression analysis selected four significant demography indicators for line regression equation:

$$
y=-2.7375+21.206 x_{1}+0.1845 x_{2}+(-1.8497) x_{3}+2.137 x_{4},
$$

where: $y$ - Armed forces personnel (\% of total labour force), $x_{1}$ - Population growth rate, $x_{2}$ - Population median age, $x_{3}$ - Total fertility rate, $x_{4}-$ Birth rate.

Each step adds a demographic indicator with the lowest $\mathrm{p}$ value:

1. Adding $x_{2}$, FStat $=43.5253$, pValue $=1.99643 \mathrm{e}-06$,

2. Adding $x_{3}$, FStat $=38.606$, pValue $=5.72511 \mathrm{e}-06$,

3. Adding $x_{1}$, FStat $=7.3845$, pValue $=0.014118$,

4. Adding $x_{4}$, FStat $=4.9928$, pValue $=0.03917$.

Mortality rate and emigration growth rate were not included in the equation because no sufficiently reliable coefficients had been found. The estimated coefficients, errors, T-statistics, and $\mathrm{p}$ value are shown in Table 3. Population growth rate has the biggest influence on Armed Forces Personnel.

Other reliability parameters of the regression equation:

Number of observations: 22, Error degrees of freedom: 17,

Root Mean Squared Error: 0.124,

R-squared: 0.943, Adjusted R-Squared: 0.93,

F-statistic vs. constant model: 70.4, p-value $=2.37 \mathrm{e}-10$. 
Table 3. Equation estimated coefficients (source: authors' calculation)

\begin{tabular}{|l|l|l|l|l|}
\hline \multicolumn{1}{|c|}{ Intercept and variables } & \multicolumn{1}{c|}{ Estimate } & \multicolumn{1}{c|}{ Error } & \multicolumn{1}{c|}{ T-stat } & \multicolumn{1}{c|}{ P-value } \\
\hline Intercept & -2.7375 & 0.43432 & -6.303 & $7.9413 \mathrm{e}-06$ \\
\hline $\mathrm{x} 1$ & 21.206 & 6.1994 & 3.4206 & 0.0032588 \\
\hline $\mathrm{x} 2$ & 0.1845 & 0.013013 & 14.178 & $7.5496 \mathrm{e}-11$ \\
\hline $\mathrm{x} 3$ & -1.8497 & 0.22905 & -8.0755 & $3.2109 \mathrm{e}-07$ \\
\hline $\mathrm{x} 4$ & 2.137 & 0.95637 & 2.2345 & 0.03917 \\
\hline
\end{tabular}

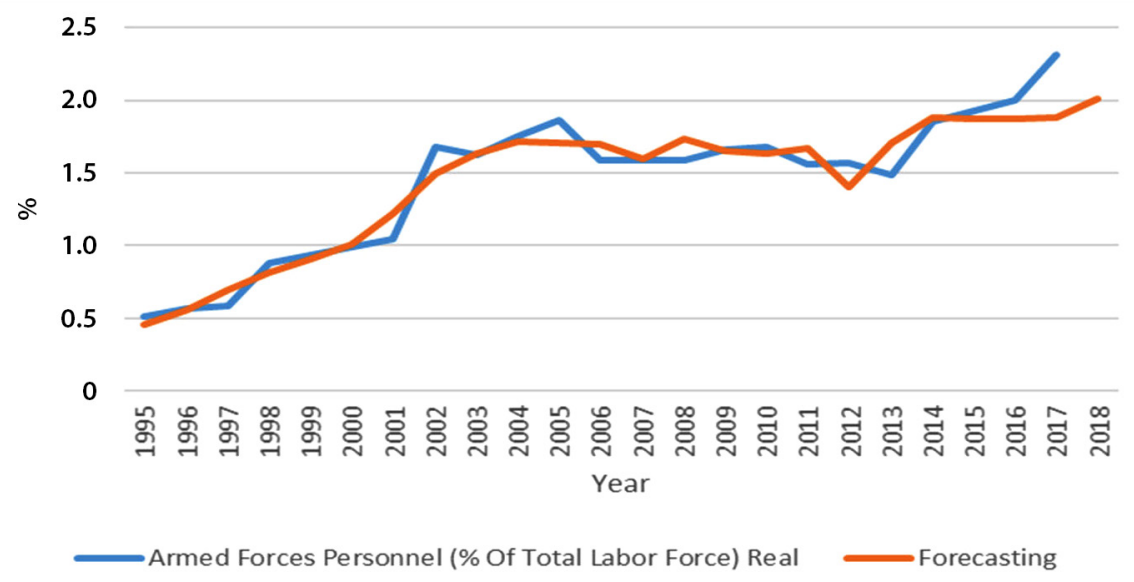

Figure 2. Comparison of dynamic of real Armed Forces Personnel and forecast by (1) regression equation (source: authors' calculation)

A graphical comparison of the actual number of emigrants with the forecast using regression equation (1) (Figure 2) suggests that there is a relationship between Armed Forces Personnel (\% of total labour force) and Population Growth Rate, Median Age of Population, Total Fertility Rate and Birth Rate.

\subsection{Forecasting by using Monte Carlo method}

All selected military and demographic indicators were predicted using historical data from 1992 to 2019. The previous dynamics of all indicators is presented in the graphic representation and reflects the historical periods of this country. The forecast for the next 10 years is presented as the most likely scenario, alongside with the marginal scenarios: pessimistic and optimistic.

Armed Forces personnel ( $\%$ of total labour force). The number of the Armed Forces personnel expressed as a percentage of the total labour force within the period after Lithuania regained its independence until joining the NATO in 2004 was growing from $0.5 \%$ to $0.57 \%$. From 2005 until 2013 it was showing decline to 1.5\%, while within the period from 2014 to 2017 it grew up to $2.4 \%$ (Figure 3). 


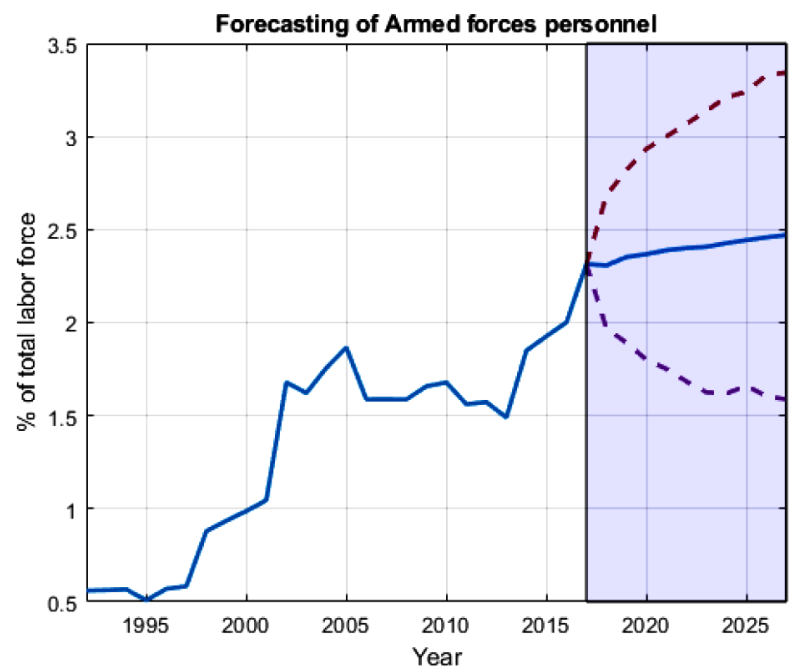

Figure 3. History and forecasting of Armed Forces personnel (source: authors' calculation)

The forecast, obtained using Monte Carlo method, suggests a steady slight increase in the indicator value. Most likely, it is related to population decline predicted in Lithuania. The maximum and minimum values of the indicator are predicted to be within the range [1.6; 3.3].

Population growth rate. This indicator used to be negative within the entire time period of research having two values showing clear falling down $(-0.019$ and -0.028$)$ in 2007 and 2012. The most likely scenario shows this indicator being stable sufficiently and fluctuating around -0.005 . The optimistic scenario predicts -0.001 , while the pessimistic one - only -0.021 (Figure 4).

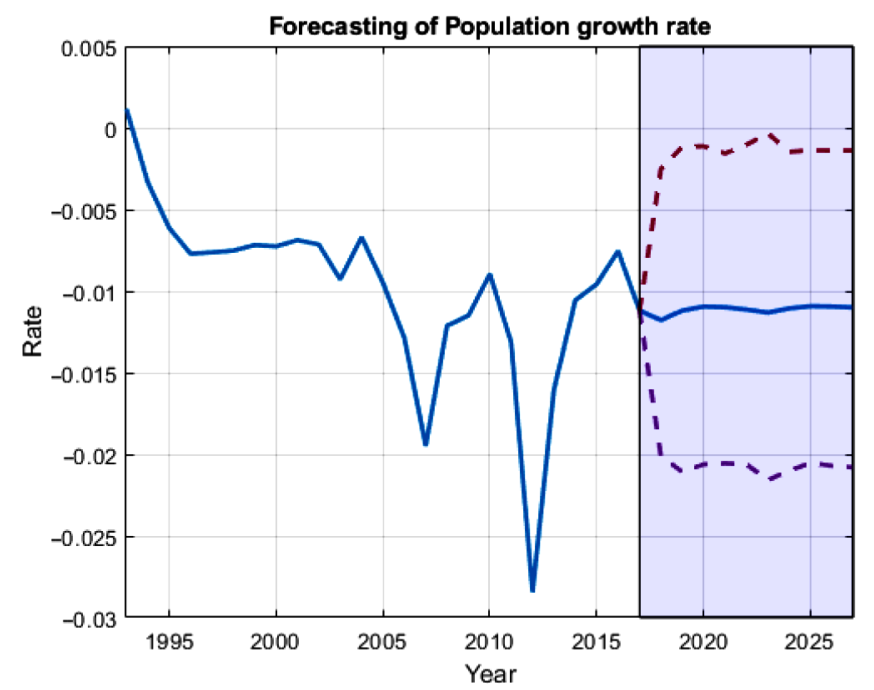

Figure 4. History and forecasting of the population median age (source: authors' calculations) 


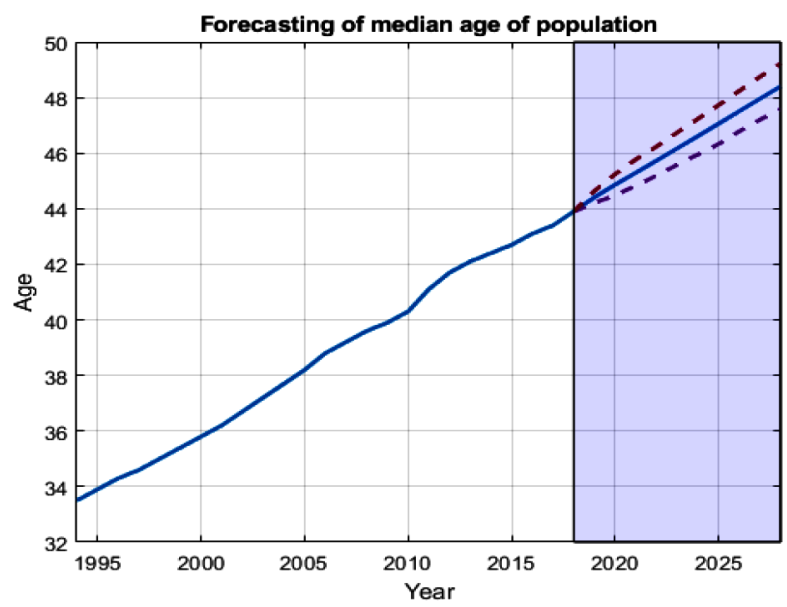

Figure 5. History and forecasting of the population median age (source: authors' calculation)

Population median age. Since the year 1992, Lithuania's population median age has shown growth from 32.9 years to 44.1 years in 2019 (Figure 5). The forecast displays linear growth of the median: in 2025 the median age of the population will reach 47 years, while in 2029 it will have the value of 48.2 years. The forecast shows a rapid process of ageing in society. Both, the pessimistic and optimistic scenarios are very close to the most likely one.

Total fertility rate. The total fertility rate in this country was decreasing within the period from 1994 to 2002 (Figure 6), it reached the value of 1.23 and started to grow. In 2015, the value it had reached was 1.7, then dropped again to 1.63 . The forecasting shows that this indicator will slightly decline over the next 10 years. The optimistic scenario demonstrates that this one may show growth to 1.9 , while the pessimistic one displays that it may drop to 1.25 .

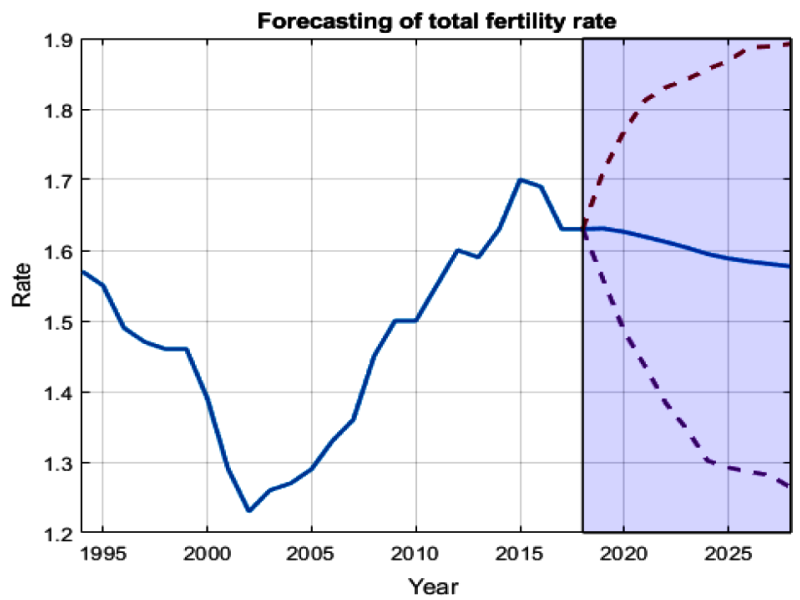

Figure 6. History and forecasting of the total fertility rate (source: authors' calculations) 
Birth rate forecasting. The birth rate within the research period jumps unevenly (Figure 7). The highest rate of decline in birth rate was in 2001, 2010 and 2017, while the increase in this rate was seen in 2003, 2008 and 2015. The forecasting shows a slight stability: the birth rate should fluctuate around -0.01 . According to the optimistic scenario, the birth rate may reach 0.06 , while according to the pessimistic one - it may drop to -0.08 .

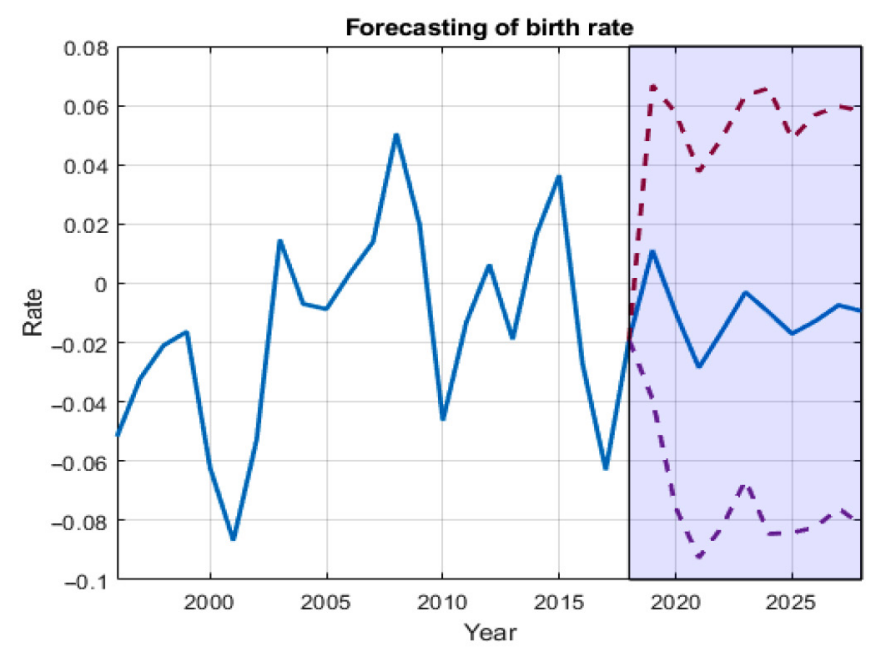

Figure 7. History and forecasting of the birth rate (source: authors' calculation)

The detected relationship between military sector and demographic trends, population estimates and future projections could allow the Government to incorporate the information received into the policies of planning and sustainable development in Lithuania. The change in demographic situation presents challenges to sustainable development goals related to well-being, poverty, inequality, social exclusion, education and promoting productive employment in military sector. Moreover, population trends have impact on military service. As people grow older, their needs, health and what they value can change. Lithuania will have to adapt to a new demographic situation.

\subsection{Discussion}

As previously mentioned, the originality of the study lies in the lack of research that combines three important economic aspects such as demographic, military and sustainable development. Also, this research expands the range of scientific studies and may be an incentive for other researchers to conduct similar investigations in their own countries and to compare the obtained results with Lithuania. Ensuring the functioning of the military sector contributes to public security. The research assesses the potential influence of demographic changes on the military personnel. The results of the research have shown that population growth rate, population age, total fertility rate as well as birth rate have impacted on the tendencies of armed forces personnel. Considering that the growth of military personnel and a rapid ageing process, also a decline in fertility rate, and fluctuations in the birth rate are expected in the next ten years, the Lithuanian military sector may face the problem of shortage of 
young and healthy people. Military labour market requires the personnel with distinctive characteristics, such as operating in hazardous conditions, working long hours with the probability of injury and death, liability to deployment to any place of the world (Hartley, 2011). Also, military personnel embrace the life-cycle. The period of 40 years involves the processes of personnel recruitment, training, retention and retirement (Hartley, 2011). Moreover, demographic changes present challenges for sustainable development related to poverty, inequality, well-being, promoting productive employment and making human settlements safe and sustainable (United Nations, 2017). This research has supported the previous studies of the United Nations (2019) and Vasyltsiv and Tesliuk (2020), which have revealed, that the global population is still growing, but some countries are experiencing a decline in their total population, all countries are experiencing population ageing, and the levels of population fertility have declined around the globe. Moreover, the authors agree with the insights of Arltová et al. (2016) presenting that population ageing is not only a demographic problem, as it impacts on the entire economy, especially in the area of expected decline in number of people of productive age and healthcare. Also, this research reflects the insights of Libicki et al. (2011), that demographic changes create problem and opportunities for the military sector. The estimates of demographic changes impact on military future projections allow government of Lithuania to incorporate information into planning and development policy. The authors suggest the main directions of the implementation of the findings as follows: 1) to incorporate the insights into the Lithuanian policy of sustainable development, 2) to implement the results in the planning process of the military personnel, 3) to use the findings expanding the range of research in other countries, 4) to apply insights in university studies by teaching subjects related to defence economics, human resource management, public safety, and others. In this research, the authors estimated the impact of demographic factors on the military personnel, however, the effects of demographic and military sector indicators on sustainable development goals have been revealed only at the theoretical level. This could be identified as a major limitation of this investigation. The authors acknowledge, that the attempt of this research is maybe incomplete and disputable. Supplementary investigations are necessary in order to outline a largely accepted methodology of quantitative evaluation of the demographic and military trends on the goals achievement of sustainable development. However, this idea is for other research.

\section{Conclusions}

The research aims at providing the more reliable estimates of the military and demographic interrelations in Lithuania. Demographic trends are essential for military sector as well as for assessment of progress towards the achievement of the Sustainable development goals. Moreover, the change in demographic situation presents challenges for sustainable development goals related to well-being, poverty, inequality, social exclusion, education, climate change, employment and others.

The investigation allows identifying the combination of the demographic factors having an impact on the change in armed forces personnel as a share of total labour force. Population growth rate, population median age, total fertility rate as well as birth rate explain 
approx. 93\% of the variation in armed forces personnel. Selected military and demographic indicators have been predicted using Monte Carlo method and historical data reflecting the period from 1992 to 2019 . The forecast has been obtained for the next 10 years. The Monte Carlo method has shown a steady slight increase in armed forces personnel as a share of total labour force. Population growth rates have been projected to remain reasonably stable. Moreover, the forecast has showed a rapid ageing process. The median age of population will reach 47 years in 2025 and 48 years in 2029. The forecast of total fertility rate has shown a slight decline over the next 10 years. Insignificant fluctuations in the birth rate have been predicted as well. Population growth rates, a rapid ageing process, decline in fertility rate are particularly relevant to the Lithuanian military services as well as sustainable development goals related to inequalities, poverty, promoting employment, ensuring healthy lives and wellbeing, and making public safety and resilient.

The authors suggest the main directions of the implementation of the findings as follows: 1) to incorporate the insights into the Lithuanian policy of sustainable development, 2) to implement the results in the planning process of the military personnel, 3) to use the findings expanding the range of research in other countries, 4) to apply insights in university studies by teaching subjects related to defence economics, human resource management, public safety, and others. We acknowledge, that the attempt of this research is maybe incomplete and disputable. The effects of demographic and military sector indicators on sustainable development goals have been revealed only at the theoretical level. This is a major limitation of this investigation. In the future, supplementary investigations are necessary in order to outline a largely accepted methodology of quantitative evaluation of the demographic and military trends on the goals achievement of sustainable development.

\section{Funding}

This work was partially supported by the Ministry of National Defence of the Republic of Lithuania.

\section{Author contributions}

GD, IMK and NM conceived the study and were responsible for the design and development of the data analysis. GD, NM were responsible for data collection and analysis. NM were responsible for data interpretation. GD wrote the first draft of the article. IMK wrote the final version of the paper.

\section{References}

Alptekin, A., \& Levine, P. (2012). Military expenditure and economic growth: a meta-analysis. European Journal of Political Economy, 28, 636-650. https://doi.org/10.1016/j.ejpoleco.2012.07.002

Anwar, M. A., Rafique, Z., \& Joiya, S. A. (2012). Defense spending-economic growth nexus: A case study of Pakistan. Pakistan Economicand Social Review, 50(2), 163-182. 
Arltová, M., Smrčka, L., Vrabcová, J., \& Schönfeld, J. (2016). The ageing of the population in developed countries - the economic consequences in the Czech Republic. Economics and Sociology, 9(2), 197-219. https://doi.org/10.14254/2071-789X.2016/9-2/14

Baumgärtner, S., \& Quaas, M. (2010). What is sustainability economics? Ecological Economics, 69, 445-450. https://doi.org/10.1016/j.ecolecon.2009.11.019

Becker, W. S. (2011). The value of sustainability to the military: preventing wars is as important as winning them, and far less costly. https://thinkprogress.org/the-value-of-sustainability-to-the-militarypreventing-wars-is-as-important-as-winning-them-and-far-25252f33db30/

Breland, J. Y., Donalson, R., Nevedal, A., Dinh, J. V., \& Maguen, S. (2017). Military experience can influence women's eating habits. Appetite, 118, 161-167. https://doi.org/10.1016/j.appet.2017.08.009

Chou, H.-W., Tzeng, W.-C., Chou, Y.-C., Yeh, H.-W., Chang, H.-A., Kao, Y.-C., Huang, S.-Y., Yeh, C.-B., Chiang, W.-S., \& Tzeng, N.-S. (2016). Stress, sleep and depressive symptoms in active duty military personnel. The American Journal of the Medical Sciences, 352(2), 146-153.

https://doi.org/10.1016/j.amjms.2016.05.013

d'Agostino, G., Dunne, J. P., \& Pieroni, L. (2018). Military expenditure, endogeneity and economic growth. Defence and Peace Economics, 30(5), 509-524.

https://doi.org/10.1080/10242694.2017.1422314

Danek, T. (2013). Analysis of relationship between military expenditure and economic growth. The Business and Management Review, 3(3), 51-57.

Dimitraki, O., \& Win, S. (2020). Military expenditure economic growth nexus in Jordan: An application of ARDL Bound test analysis in the presence of breaks. Defence and Peace Economics. https://doi.org/10.1080/10242694.2020.1730113

Dunne, J. P., Smith, R. P., \& Willenbockel, D. (2005). Models of military expenditure and growth: A critical review. Defence and Peace Economics, 16(6), 449-461. https://doi.org/10.1080/10242690500167791

Dunne, J. P., \& Tian, N. (2015). Military expenditure, economic growth and heterogeneity. Defence and Peace Economics, 26(1), 15-31. https://doi.org/10.1080/10242694.2013.848575

Eurostat. (2019). https://ec.europa.eu/eurostat/data/database

Foster, S. N., Hansen, S. L., Capener, D. C., Matsangas, P., \& Mysliwiec, V. (2017). Gender differences in sleep disorders in the US military. Sleep Health, 3, 336-341.

https://doi.org/10.1016/j.sleh.2017.07.015

Guo, D., Sun, L., Yu, X., Liu, T., Wu, L., Sun, Z., Zhang, F., Zhou, Y., Shen, M., \& Liu, W. (2019). Mindfulness-based stress reduction improves the general health and stress of Chinese military recruits: A pilot study. Psyhiatry Research, 281, 1-5. https://doi.org/10.1016/j.psychres.2019.112571

Hartley, K. (2011). The economics of defence policy. A new perspective. Routledge. https://doi.org/10.4324/9780203838778

Kalyoncu, H., \& Yucel, F. (2006). An analytical approach on defense expenditure and economic growth: The case of Turkey and Greece. Journal of Economic Studies, 33(5), 336-343. https://doi.org/10.1108/01443580610706564

Karadam, D. Y., Yildirim, J., \& Nadir, Ö. (2017). Military expenditure and economic growth in Middle Eastern countries and Turkey: A non-linear panel data approach. Defence and Peace Economics, 28(6), 719-730. https://doi.org/10.1080/10242694.2016.1195573

Knell, M. (2005). Demographic fluctuations, sustainability factors and intergenerational fairness - an assessment of Austria's new pension system. Monetary Policy \& the Economy Q, 1, 23-42.

Libicki, M. C., Shatz, H. J., \& Taylor, J. E. (2011). Global demographic change and its implication for military power. https://www.jstor.org/stable/10.7249/mg1091af.14?seq=1\#metadata_info_tab_contents

Lin, F-L., \& Wang, M.-C. (2019). Does economic growth cause military expenditure to go up? Using MFVAR model. Quality \& Quantity, 53, 3097-3117. https://doi.org/10.1007/s11135-019-00921-6 
López Subires, M. D., Alcaide Muñoz, L., Navarro Galera, A., \& Rodríguez Bolívar, M. P. (2019). The influence of socio-demographic factors on financial sustainability of public services: a comparative analysis in regional governments and local governments. Sustainability, 11(21), 6008. https://doi.org/10.3390/su11216008

Lutz, W., Testa, M. R., \& Penn, D. J. (2006). Population density is a key factor in declining human fertility. Population and Environment, 28, 69-81. https://doi.org/10.1007/s11111-007-0037-6

Malthus, T. R. (1978). An essay on the principle of population, printed for J. Johnson, in St. Paul's Church-Yard, London. http://www.esp.org/books/malthus/population/malthus.pdf

Markowski, S., Chand, S., \& Wylie, R. (2017). Economic growth and demand for military expenditure in the Indo-Pacific Asia region. Defence and Peace Economics, 28(4), 473-490. https://doi.org/10.1080/10242694.2016.1274059

MatLab. (2019). https://ch.mathworks.com/help/econ/vec-model-monte-carlo-forecasts.html

Meidutè-Kavaliauskienė, I., Dudzevičiūtè, G., Maknickienė, N., \& Vasilis Vasiliauskas, A. (2020). The relation between aging of population and sustainable development of EU countries. Entrepreneurship and Sustainability Issues, 7(3), 2026-2042. https://doi.org/10.9770/jesi.2020.7.3

NATO. (2019). Defence expenditure of NATO countries. https://www.nato.int/cps/en/natohq/ news_164482.htm

Phiri, A. (2017). Does military spending nonlinearly affect economic growth in South Africa? Defence and Peace Economics, 30(4), 474-487. https://doi.org/10.1080/10242694.2017.1361272

Prokurat, S., \& Fabisiak, J. (2018). Current demographic trends induced by changing fertility patterns in Europe and the United States. Studia Prawno-Ekonomiczne. https://doi.org/10.26485/SPE/2018/106/18

Saba, C. S., \& Ngepah, N. (2019). A cross-regional analysis of military expenditure, state fragility and economic growth in Africa. Quality \& Quantity, 53, 2885-2915. https://doi.org/10.1007/s11135-019-00905-6

Salvati, L., Carlucci, M., Serra, P., \& Zambon, I. (2019). Demographic transitions and socioeconomic development in Italy, 1862-2009: A brief overview. Sustainability, 11(1), 242. https://doi.org/10.3390/su11010242

Shahbaz, M., Afza, T., \& Shabbir, M. S. (2013). Does defence spending impede economic growth? Cointegration and causality analysis for Pakistan. Defence and Peace Economics, 24(2), 105-120. https://doi.org/10.1080/10242694.2012.723159

Thompson, W. S. (1929). Population. American Journal of Sociology, 34(6), 959-975. https://doi.org/10.1086/214874

United Nations. (2019). World Population Prospects. https:/population.un.org/wpp/Publications/Files/ WPP2019_Highlights.pdf

United Nations. (2017). Ageing, older persons and the 2030 agenda for sustainable development. https:// www.undp.org/content/undp/en/home/librarypage/poverty-reduction/ageing--older-persons-andthe-2030-agenda-for-sustainable-develo.html

Utrero-Gonzalez, N., Hromcova, J., \& Callado-Muńoz, F. J. (2019). Defence spending, institutional environment and economic growth: Case of NATO. Defence and Peace Economics, 30(5), 525-548. https://doi.org/10.1080/10242694.2017.1400292

Vasyltsiv, T., \& Tesliuk, R. (2020). Demographic dimention of sustainable development of Ukraine. Ekonomika ta derzhava, 4, 33-38. https://doi.org/10.32702/2306-6806.2020.4.33

Vest, B. M., Homish, D. L., Fillo, J., \& Homish, G. G. (2018). Military status and alcohol problems: Former soldiers may be at greater risk. Addictive Behaviors, 84, 139-143.

https://doi.org/10.1016/j.addbeh.2018.04.011 
World Bank. (2016). Global monitoring report 2015/2016: Development goals in an era of demographic change. World Bank, Washington, DC. http://pubdocs.worldbank.org/en/503001444058224597/ Global-Monitoring-Report-2015.pdf.

World Bank. (2019). https://data.worldbank.org/indicator/MS.MIL.TOTL.TF.ZS?locations=LT\&most_ recent_year_desc=false

Yang, A. J. F., Trumbull, W. N., Yang, C. W., \& Huang, B.-N. (2011). On the relationship between military expenditure, threat, and economic growth: a nonlinear approach. Defence and Peace Economics, 22(4), 449-457. https://doi.org/10.1080/10242694.2010.497723

Yildirim, J., \& Sezgin, S. (2003). Military expenditure and employment in Turkey. Defence and Peace Economics, 14(2), 129-139. https://doi.org/10.1080/10242690302919

Zhang, Y., Wang, R., \& Yao, D. (2017). Does defence expenditure have a spillover effect on income inequality? A cross-regional analysis in China. Defence and Peace Economics, 28(6), 731-749.

https://doi.org/10.1080/10242694.2016.1245812 